Beyond Philology No. 16/1, 2019

ISSN 1732-1220, eISSN 2451-1498

https://doi.org/10.26881/bp.2019.1.01

\title{
The speech act of threatening in German and Polish: Semantic and pragmatic aspects
}

\author{
JOANNA MISIUKAJTIS
}

Received 8.02.2019, received in revised form 4.04.2019, accepted 11.04.2019.

\begin{abstract}
The major objectives of this study are to attempt to situate the speech act of threatening in the classification of speech acts and - on the basis of the linguistic and social factors conditioning the use of this speech act - to define the speech act of threatening for the purpose of analyzing the linguistic material. Additionally, the paper seeks to propose the main structure of the aforementioned speech act and a variety of factors conditioning its use in modern German and Polish.

The primary object of research in this work is the speech act of threatening analysed within the methodology of pragmalinguistics. The research material is composed of examples of the speech act of threatening in modern spoken Polish and German.

The analysis of the speech act of threatening presented in this study is an introduction and it will be further elaborated on in a monograph study of this topic.
\end{abstract}

\section{Keywords}

speech act, threatening, pragmalinguistics, directive speech acts 


\title{
Akt mowy groźba we języku niemieckim i polskim: Aspekty semantyczno-pragmatyczne
}

\begin{abstract}
Abstrakt
Celem artykułu jest $z$ jednej strony próba usytuowania aktu mowy groźba w klasyfikacji aktów mowy i na podstawie językowospołecznych uwarunkowań funkcjonowania tego aktu zdefiniowanie aktu mowy groźba dla potrzeb materiału, $z$ drugiej zaś strony przedstawienie propozycji zasadniczej struktury danego aktu i jego różnorodnych uwarunkowań funkcjonowania we współczesnym języku niemieckim i polskim.

Materiał badawczy stanowić będa przykłady użycia aktu mowy groźba we współczesnym języku polskim i niemieckim. Podstawa doboru materiału badawczego jest polski i niemiecki język mówiony, zawierający groźbę w różnych kontekstach językowych.

Prześledzona analiza aktu mowy groźba stanowi wprowadzenie $\mathrm{w}$ bogate pragmatycznie zagadnienie funkcjonowania aktu mowy groźba w języku polskim i niemieckim. Przedstawiona problematyka znajdzie szerszy opis w przygotowywanej monografii na ten temat.
\end{abstract}

\section{Słowa kluczowe}

akty mowy, dyrektywne akty mowy, groźba, pragmalingwistyka

\section{Introduction}

The primary object of research in this work is the speech act of threatening analysed within the methodological framework of pragmalinguistics. The research material consists of examples of the speech act of threatening in modern Polish and German. The spoken Polish and German language samples containing the threat in various linguistic contexts are subject to scrutiny.

The major objective of this study is twofold. First of all, it attempts to situate the speech act of threatening in the classification of speech acts and - on the basis of the linguistic and social factors conditioning the use of this speech act - to 
define the speech act of threatening for the purpose of analyzing the linguistic material. Secondly, the paper also seeks to propose the main structure of the aforementioned speech act and a variety of factors conditioning its use in modern German and Polish.

In Polish and German linguistics, the pragmatics of speech acts has been the object of research for, among others, Awdiejew (2004), Havryliv (2009: 99-109), Kantorczyk (2008), Komorowska (2006: 293-300, 2008), Marcjanik (2007), Nęcki (2005), Ożóg (1982: 259-266), Pisarkowa (1976), Prokop (2010), Pytel-Pandey (2014: 357-366) and Wierzbicka (1973), to mention just a few.

\section{The speech act of threatening in the classification of speech acts}

The speech act of threatening is an act which is usually related to commissive speech acts (according to the division introduced by both Austin (1962) and Searle (1999)). Commissive speech acts (also known as commissives) - as seen for example, by Searle (1999) - are a kind of addresser's obligation to take specific action in the future. Austin expands this definition and claims that the obligations towards the addressee are linked to promising something or to disclosing some intentions, which means that they are related to plans of future action (Prokop 2010). Such speech acts as pledges, promises, oaths and obligations belong to the commissive category. The meaning which is derived from the definition of this speech act implies that it is one of the commissive speech acts. A threat is thus seen as some kind of obligation on the part of the addresser to perform specific actions. However, this obligation may not bring any benefits to the addressee, as in the case of the speech act of promising. Instead, the threat can bring sanctions which may be anticipated by the addressee if some predefined conditions are not met. Wunderlich (1978) is one of the linguists who classify the speech act of threatening as an example of commissive speech acts. 
Some linguists, among them Prokop (2010) and Awdiejew (2004), question the placement of the speech act of threatening among the commissive speech acts, claiming that in the speech act of threatening, there are some factors which are typical of a different speech act group, namely directive speech acts. It is worthwhile to stress that the specific character of threats, which makes this speech act different from other commissive speech acts, was already noticed by Searle (1999), who emphasized the difference in referring a given speech act to benefits or to the lack of benefits in the performance of this speech act. Thus, in such speech acts as promise, oath or obligation, what can be seen is the activity for the benefit of the addressee. However, in the case of the speech act of threatening, it is not the benefit of the addressee but rather potential acts against the addressee, to his or her detriment. Therefore, this speech act is not fully compatible with the definition of the other speech acts which form the group of commissives.

Interestingly enough, the directive speech act seems to be semantically closer to the speech act of threatening. Directive speech acts (directives) ${ }^{1}$ are acts urging the addressee to perform specific actions or conversely to stop performing them. To put it differently, "the essence of directive speech acts is the addresser's will to control the addressee in terms of stimulating him/her to perform certain physical or psychological actions" (Kantorczyk and Komorowska 2008: 26, trans. Walczyński). Thus, the speech act of threatening can be understood in this way since it aims to urge the addressee to perform some activity. In their study entitled Pragmatyka dyrektywnych aktów mowy $w$ języku niemieckim, polskim $i$ rosyjskim, Komorowska and Kantorczyk (2008: 28) offer the division of directive speech acts into two major groups:

\footnotetext{
1 "In the linguistic literature, there is no terminological unanimity related to the so-called "directive speech acts". There are several different designations: "the speech acts stimulating activity", "directive speech acts", "exercitives", "acts controlling behaviours", "urging" or "demanding"” (Komorowska 2008: 24, trans. Walczyński).
} 
obliging speech acts and non-obliging speech acts with the division criterion being the fulfilment of the basic condition "pointing to the sanctions which can be imposed on the addressee in case the activity is not performed" (trans. Walczyński). Non-obliging speech acts are speech acts in which "the non-performance of the activity is related to no sanction" (trans. Walczyński), e.g. request, offer, advice. In the case of obliging speech acts, "the non-performance of the activity entails some sanctions" (trans. Walczyński), e.g. demand, order, ban. Although among the specified linguistic behaviours the authors did not analyse the speech act of threatening, this speech act is a member of the group of obliging directive speech acts. The scholars also used another criterion in their classification. They defined three semantic properties of the directive speech acts which involved specifying the benefits which are derived from performing some activity (Kantorczyk and Komorowska 2008: 28). Three possible variations of the benefits derived from performing the activity were distinguished: in the interests of the speaker (request, demand, order), in the interests of the addressee (advice, recommendation, explanation), in the interests of both interlocutors (offer) (Kantorczyk and Komorowska 2008: 29).

The division presented above shows that the speech act of threatening in terms of its semantic meaning belongs to the group of the activities performed in the interests of the speaker (Hindelang 1983). Awdiejew (2004: 138) sees the speech act of threatening (in Polish "akt mowy pogróżka"2) as the speech act which is close to the directive function of demanding. By this, Awdiejew confirms that the speech act of threatening belongs to the directives and - at the same time - he shows its semantic relation with demanding. Awdiejew claims that "it may be observed that the function of the threat is related to the overlapping function of demanding. The major difference lies in the fact that in the threat the focus is moved onto the addresser's promise, connected with performing a sanction

2 Threat - threatening with revenge, punishment, retaliation (Słownik współczesnego języka polskiego, edited by Dunaj: 788). 
which is placed in the background in the speech act of demanding. In this way, the performance of the demand included in the offer becomes the condition for avoiding the sanction. The performance of the threat involves, most of all, the exposition of this condition even if the sanctions are not specified: Spróbuj tylko nie przyjść na zebranie, to zobaczysz! (Just you try not to come to the meeting and you'll see!) (Awdiejew 2004: 138, trans. Walczyński).

Discussing speech acts, Prokop distinguishes between symmetric and asymmetric communication. "Symmetric communication is communication (a communicative event) when the addresser and the addressee have the same rights and obligations" (Prokop 2010: 15, trans. Walczyński). Asymmetric communication is communication "in which one of the partners has more rights than obligations" (Prokop 2010: 16, trans. Walczyński). In the speech act of threatening, the communication is asymmetric because the addresser is superior to the addressee and has made a decision about potential sanctions and their enforcement. ${ }^{3}$ The advantage of the addresser over the addressee can result from, for instance, the social roles they play, their professional hierarchy, emotional factors known by the addresser and the addressee, or emotional dependence.

The occurrence of the speech act of threatening is also related to a presupposed condition or conditions known to the addresser and the addressee which let the addresser threaten and the addressee accept the speech act of threatening as an act resulting from a situation which previously took place. For example, the addressee knows that he or she borrowed money from the addresser and that is why he or she is aware of the fact that the addresser has a reason for demanding the repayment. Sometimes the occurrence of the speech act of

\footnotetext{
3 Though the addresser usually has the advantage over the addressee, the reverse situation can always occur. In such a situation, the person who - in theory - is dependent may become the addresser in a given situation. For instance, if a mistreated woman runs into the kitchen, grabs a knife and threatens to kill her husband if he ever touches her again.
} 
threatening is situationally conditioned, for instance, an unknown person who unexpectedly threatens us:

(1)(a) Dawaj kase, bo ci wpierdole!

(1)(b) Raus mit der Kohle, sonst haue ich dir eine auf die Fresse! 'Give me the dough or I'll beat the shit out of you!'

\section{Defining the speech act of threatening}

After analysing the semantic and pragmatic conditions of the speech act of threatening for the purpose of studying the research material, it is possible to use to the following definition of the speech act of threatening:

Threatening is a directive speech act which has the character of an obligation, which means that it is a speech act, in which the non-performance of the activities demanded by the addresser is linked to sanctions on the addressee and which is an activity for the benefit of the addresser who is in asymmetric communication with the addressee.

The speech act of threatening is characterised by the fact that there is typically no use of the verb "threaten" in the performative function, e.g. ja ci groże (Ich drohe dir / I'm threatening you) or My wam grozimy (Wir drohen euch / We are threatening you). This suggests that this verb is not used in the first person singular or plural in the performative function. It may be accounted for by the meaning of threat which, because of the semantics of aggression included in it, is usually a covert speech act, from which - by implication and contextualisation - the actual threatening intention of the addresser, i.e. the illocution of the speech act threat, is derived. An expression such as Ja ci grożę (Ich drohe dir / I'm threatening you) is so incongruous as a real speech act of threatening that its contextual use can perform the function of a joke or be the exponent of the interlocutors' wordplay. For example, in the joking conversations of spouses: 
(2)(a) Jak mnie teraz nie pocałujesz, to nie będzie obiadu! To jest groźba!

(2)(b) Wenn du mich nicht sofort küsst, gibt es kein Mittagessen! Das ist eine Drohung!

'If you don't kiss me now, don't expect any dinner! It's a threat!'

A wife saying to her husband:

(3)(a) Jak mnie nie zabierzesz do Paryża $w$ przyszłym tygodniu, to pojade sama i znajde sobie jakiegoś miłego Francuza. Mówie poważnie!

(3)(b) Wenn du mit mir nächste Woche nicht nach Paris fährst, werde ich alleine fahren und mir einen netten Franzosen suchen. Das meine ich ernst!

'If you don't take me to Paris next week, I'll go alone and find myself some nice French guy. Seriously!'

In a dialogue between friends:

(4)(a) Nie uśmiechaj się tak intensywnie do mojego narzeczonego. Ja wszystko widzę! On jest już mój. Uważaj!

(4)(b) Lächle meinen Verlobten nicht so intensiv an! Ich sehe alles! Er ist schon vergeben! Pass auf!

'Don't you smile so intently at my fiancé. I can see everything! He's mine already. Watch out!'

Apparently in such a communicative situation a significant role is played by the appropriate intonation of the joke and by extralinguistic means such as facial expressions, squinting eyes, smiling etc.

However, as mentioned earlier, in the speech act of threatening, usually the verb "threaten" is not implemented in the performative function and the intention of the threat is derived by inference from the addresser's utterance. In the dialogic form, we can bring the meaning of threatening to the surface of language, for instance: 
(5)(a) Czy ty mi grozisz?

(5)(b) Drohst du mir?

'Are you threatening me?'

The interlocutor's response can be varied depending on the situation, including responses with the use of the performative verb, for example:

(6)(a) Tak, właśnie ci grożę.

(6)(b) Ja, ich drohe dir gerade.

'Damn right, I am threatening you.'

or without the performative verb:

(7)(a) Co ty opowiadasz? Co się wygtupiasz? etc.

(7)(b) Was redest du denn? Sag mal, spinnst du?

'What are you talking about? You are talking nonsense' etc.

(Misiukajtis 2008: 109)

In the speech act of threatening, there is usually no use of the "threaten" verb in the performative function. In verbal communication, it is the character of the speech act of threatening involving the pragmatic complexity that assumes the function of the performative. This act can be expressed by employing the exponents of other directive speech acts such as request, advice and offer, for example:

(8)(a) Ja cie grzecznie prosze, zostaw mnie $w$ spokoju, bo ci zajebię.

(8)(b) Ich bitte dich ganz höflich, lass mich in Ruhe, sonst haue ich dir eine auf die Fresse.

'I'm asking you nicely to leave me alone or else I'll fucking beat you up.'

(9)(a) Ja ci dobrze radzę, oddaj mi kase, bo wypadki chodza po ludziach.

(9)(b) Ich rate dir, gib mir die Kohle zurück, sonst könnte ein Unglück passieren.

'Take my advice, give me my dough back. Shit happens, you know.' 
(10)(a) Proponuję ci wspótpracę, bo skończysz tak, jak twój kolega, który nie skorzystał $z$ tej oferty.

(10)(b) Ich biete dir eine Zusammenarbeit an, sonst könntest du so enden wie dein Kumpel, der das Angebot nicht angenommen hat.

'I'm offering you cooperation or you'll end up like this friend of yours who hasn't accepted my offer.'

The complex character of the speech act of threatening results not only from the use of the exponents of other directive speech acts but is also strengthened by proper intonation, tone of voice and extralinguistic means such as threatening gestures, facial expressions, the addresser's posture etc.

\section{The structure of the speech act of threatening}

The linguistic material presented above shows that the speech act of threatening is composed of three major components:

- The first major component of the speech act of threatening (C1) is the situational context which can be an existing or repeating situation, or other factors influencing the addresser. This situational context can have criminal, psychological or emotional roots.

- The second major component of the speech act of threatening (C2) is the imposition of the condition of the demand on the addressee by the addresser.

- The third major component of the speech act of threatening (C) is the sanctions or consequences which will take place in the event that the addressee does not fulfil the condition/s imposed by the addresser.

The proposed structure of the speech act of threatening can be visualised as follows:

component $1(\mathrm{C} 1)+$ component $2(\mathrm{C} 2)+$ component 3 (C3)

The first component of the speech act of threatening is the situational context (SC) which is made up of the situational 
and contextual knowledge (world knowledge, knowledge of conditions and experience as well as knowledge of a given situation). Moreover, this component is also constituted by pragmatic factors such as the relations between the addresser and the addressee, their social roles, the emotional relationship between them, the presupposed knowledge related to a given conflict situation, the essence of the conflict etc. The situational context is non-verbal in character. It allows the condition of the speech act of threatening to be understood.

The second and third components are the major components of the speech act of threatening which are constituted by the addresser's demand from the addressee and the specification of the sanctions which will take place if the addresser's demand is unfulfilled.

In the linguistic material of the speech act of threatening under analysis, we can distinguish the basic structure of this act which can be represented schematically in the following way:

$\mathrm{C} 1[\mathrm{SC}$ (situational context)] + C2 [AR (addresser) imposes Con (condition) AE (on addressee)

and if the $\mathrm{AE}$ (addressee) does not fulfil it, $\mathrm{AR}$ threatens $\mathrm{AE}$ saying:

B (no + behaviour)], then+ C3 [S (sanction)]

Abbreviations:

$$
\begin{aligned}
& \text { CS - situational context } \\
& \text { AR - addresser } \\
& \text { Con - condition } \\
& \text { AE - addressee } \\
& \text { B - behaviour } \\
& \mathrm{S} \text { - sanction }
\end{aligned}
$$




\section{The patterns of the structure of the speech act of threatening}

C1[CS (A father comes home after a parents' meeting at school and finds his son on the internet)] + C2 [AR (The father) imposes Con (condition) A (on the son): If B (if you do not start learning), then], then + $\mathbf{C} 3$ [S (I will not buy a new computer for you)]

C1[SC (The son's classmate continually provokes the addresser's son, threatening him] + C2 [AR (The threatened boy's father) imposes Con (condition) A (on the son's classmate who provokes and threatens the son) saying:

If B (you do not stop provoking and threatening my son), then], then + C3 [S (I will call the police).

Selected examples:

(11)(a) Jeśli będziesz mi Pan dalej grozit, zgłoszę sprawe na policję.

(11)(b) Wenn Sie mir weiter drohen, melde ich es bei der Polizei. 'If you keep threatening me, I will tell the police.'

(12)(a) Jeśli spróbujesz wsiaść pijany za kierownice, zgłosze to na policję.

(12)(b) Wenn du versuchst, dich betrunken hinter das Steuer zu setzen, zeige ich dich an.

'If you even try to drink drive, I will tell the police.'

(13)(a) Jeśli nie oddasz mi pieniędzy do piatku, powiem wszystkim, że jesteś hazardzistą.

(13)(b) Wenn du mir das Geld bis Freitag nicht zurückgibst, sage ich allen, dass $d u$ spielsüchtig bist.

'If you don't give me my money back by Friday, I will tell everyone that you are a gambler.'

The speech act of threatening can contextually include various additional pieces of information which - on the one hand situates this act within the group of directive acts and - on the 
other hand - accentuates the conditions for its occurrence. The brevity of this paper does not allow for the presentation of the entirety of the exponents and conditions of the speech act of threatening and therefore in this study only selected aspects of the verbalisation of this speech act are presented.

One of these aspects is the presupposition that there is emotive and/or situation specific information which can be coded by various pragmatic frameworks, depending on the emotions.

"I am not satisfied with it/ I do not like it/ I criticise it, that you do/you do not stop doing (B) and if this does not change, I will do (S)"

Selected examples:

A mother saying to her daughter:

(14)(a) Nie podoba mi sie to, co robisz. Kilka razy cie prosiłam, abyś nie spotykała sie $z$ tym chłopakiem. Ale ty ciagle sie $z$ nim umawiasz. Jeśli nie zakończysz tej znajomości, to zastosuję areszt domowy i zabiorę ci komórkę.

(14)(b) Es gefällt mir nicht, was du machst. Ich habe dich mehrmals darum gebeten, dich nicht mit diesem Jungen zu treffen. Und du triffst dich ständig mit ihm. Wenn du diese Bekanntschaft trotzdem nicht beendest, bekommst $d u$ Hausarrest und ich nehme dir dein Handy weg.

'I don't like what you're doing. I've asked you a couple of times not to meet this guy and you still keep seeing him. If you don't break up with him, I will ground you and take your mobile.'

A teacher saying to a student:

(15)(a) Nie podoba mi się, że uciekasz z lekcji. Jeśli nie przestaniesz, to wezwe twoich rodziców. 
(15)(b) Es gefällt mir nicht, dass du die Schule schwänzt. Wenn du damit nicht aufhörst, werde ich deine Eltern darüber informieren.

'I don't like it when you play truant. If you keep doing it, I'll call your parents.'

A mother saying to her son:

(16)(a) Nie podoba mi się, że tak się wyrażasz. Nie lubię tego. Jeśli beqdziesz przeklinat, to zabiore ci kieszonkowe.

(16)(b) Es gefällt mir nicht, dass du solche Ausdrücke benutzt. Ich mag es nicht. Wenn du weiter fluchst, dann werde ich dein Taschengeld streichen.

'I don't like it when you use that language. I don't. If you keep swearing, I will take your pocket money.'

A manager saying to his employee:

(17)(a) Nie podoba mi się, że ciagle rozmawia pani przez swój prywatny telefon $w$ pracy. Nie będe tego tolerowat. Prosze skoncentrować sie na pracy, inaczej dostanie pani upomnienie!

(17)(b) Es gefällt mir nicht, dass Sie ständig mit Ihrem privaten Handy auf der Arbeit telefonieren. Ich werde es nicht hinnehmen. Konzentrieren Sie sich auf Ihre Arbeit, sonst bekommen Sie eine Abmahnung!

'I don't like it when you're always talking on your phone at work. I won't put up with it. Please focus on your work or you'll be reprimanded.'

"I am sorry that you are doing it/you are not stopping it (B) and if this does not change, I will do (S)"

Selected examples:

(18)(a) Martwię się o ciebie, ale jeśli nadal będziesz pił $i$ nie podejmiesz leczenia, odejdę. 
(18)(b) Ich mache mir Sorgen um dich, aber wenn du nicht aufhörst zu trinken und keine Therapie machst, werde ich mich von dir trennen.

'I'm worried about you. If you keep drinking and avoiding rehab, I will leave.'

"I am sorry that you are doing it/you are not stopping it (B) and if this does not change, I will do (S)"

Selected examples:

(19)(a) Przykro mi, że nie masz czasu na trening. Jeśli nie poprawisz wkrótce wyników, to wyrzuce cię $z$ drużyny.

(19)(b) Es tut mir leid, dass du keine Zeit zum Trainieren hast. Aber wenn du deine Leistungen nicht bald verbesserst, werde ich dich von der Mannschaft ausschließen.

'I'm sorry that you cannot find the time for your training. If you don't improve your results, you will be off the team.'

"I am sorry that you do/you do not stop doing (B) and if this does not change, I will do (S)"

Selected examples:

(20)(a) Jestem oburzona tymi pomówieniami. Jeśli tego nie odwołasz, to poinformuje szefa o twoich blędach $w$ raporcie.

(20)(b) Ich bin empört über diese Verleumdungen. Wenn du sie nicht zurücknimmst, werde ich den Chef über deine Fehler im Bericht informieren.

'These unfounded allegations are outrageous. If you don't take them back, I'll inform the boss about the mistakes in your report.'

It is worth stressing that the presupposed information is strengthened by the adverbial lexemes confirming the continuity or frequency of the situations: nieustannie 'continually', ciagle 'all the time', bez przerwy 'continuously', notorycznie 'notoriously' etc. 
Selected examples:

(21)(a) Ty notorycznie kłamiesz! Jeśli mnie jeszcze raz oszukasz, zerwe z toba wszelkie kontakty.

(21)(b) Du lügst ständig! Wenn du mich noch mal anlügst, breche ich den Kontakt ab.

'You are a notorious liar! If you cheat me again, I will sever all contacts with you.'

(22)(a) Pani cały czas rozmawia! Jak pani nie przestanie przeszkadzać, to wyrzuce pania $z$ sali.

(22)(b) Sie reden die ganze Zeit! Wenn Sie nicht aufhören zu stören, schmeiße ich Sie raus.

'You are talking all the time! If you keep disturbing everyone, I'll throw you out of the classroom.'

(23)(a) Ciagle gubisz gdzieś swoje rzeczy! Jeśli jeszcze raz coś zgubisz, odkupisz to ze swojego kieszonkowego.

(23)(b) Du verlierst ständig deine Sachen! Wenn du noch einmal etwas verlierst, wirst du es dir von deinem Taschengeld selbst kaufen.

'You are always losing your stuff! Do it again and you'll have to buy what you lost out of your own pocket money.'

The semantic conditions of the speech act of threatening presented above also provide typical structural frameworks. These are usually such conditional clauses as:

$\mathrm{N}$ : "If you do not do/do not stop doing/do not come to your senses etc. (B), then I will use the sanction (S).

Selected examples:

(24)(a) Jeśli nie przestaniesz palić, to możesz zapomnieć o kieszonkowym.

(24)(b) Wenn du nicht aufhörst zu rauchen, dann kannst du das Taschengeld vergessen.

'If you don't quit smoking, you can forget about your pocket money.' 
(25)(a) Jeśli nie przestaniesz pić, rozwiode się z tobą!

(25)(b) Wenn du nicht aufhörst zu trinken, dann lasse ich mich von dir scheiden. 'If you keep drinking, I'll divorce you.'

(26)(a) Jeśli nie posprzatasz pokoju, to na pewno nie pójdziesz jutro do kina!

(26)(b) Wenn du das Zimmer nicht aufräumst, dann gehst du morgen bestimmt nicht ins Kino.

'If you don't tidy your room, don't even think of going to the cinema tomorrow.'

Another essential semantic issue is the kind of sanction the author of the threat chooses to inflict on the addressee. Undoubtedly, these are not be situations which are favourable to the addressee. On the contrary, there are some negative sanctions that may refer to a variety of spheres: the physical sanctions (beating), the psychological sanctions (persecuting), depriving someone of something or impeding their activities.

Selected examples:

(27)(a) Jak będziesz obrażał moja siostrę, to dostaniesz $w$ mordę!

(27)(b) Wenn du meine Schwester beleidigst, haue ich dir eine auf die Fresse!

'If you keep insulting my sister, I'll smash your face!'

(28)(a) Jeśli nie posprzatasz w pokoju, to wyrzuce twoje zabawki!

(28)(b) Wenn du dein Zimmer nicht aufräumst, schmeiße ich dein Spielzeug weg!

'If you don't tidy your room, I'll throw away your toys!'

(29)(a) Jeśli będziesz robił imprezy $w$ mieszkaniu, wyrzuce cię!

(29)(b) Wenn du in der Wohnung nur Partys machst, schmeiße ich dich raus!

'If you have a party in the flat, I will kick you out!'

\section{Conclusion}

The analysis of the speech act of threatening presented in this paper has demonstrated that it is possible to resituate this act 
within the classification of speech acts. Typically, the speech act of threatening is classified with commissive speech acts acts of obligation. However, what could be observed in the above analysis is that these are a different type of obligation which do not bring any benefits to the addressee, as is the case with the speech act of promising. The speech act of threatening involves some sanctions which can be expected if the addressee does not fulfil the predefined requirements. Arguably this act is, most of all, a directive speech act persuading the addressee to perform particular activities or to stop performing them. Thus, a threat is a speech act of obligation, in which the non-performance of an activity ordered by the addresser - the threatening person - is linked to some sanctions imposed on the addressee - the threatened person. It is an act of asymmetric communication, in which one of the partners has more rights than obligations which - he or she may think - allows him or her to impose some requirements on the addressee.

The functioning of the speech act of threatening shows its semantic complexity which is related to the fact that this act may be expressed by means of the exponents of other directive speech acts such as request, advice, proposal etc. Furthermore, a proposed structure of the speech act of threatening has been offered which not only presents the verbalisation of the threat but also takes into account the broad situational context of a given activity and the linguistic and social conditioning of its functioning in modern German and Polish. 


\section{References}

Awdiejew, Aleksy (2004). Gramatyka interakcji werbalnej. Kraków: Wydawnictwo Uniwersytetu Jagiellońskiego.

Grochowski, Maciej (1990). "O pojęciu groźby”. Polonica 14: 33-44.

Havryliv, Oksana (2009). Verbale Aggression. Frankfurt am Main: Peter Lang Internationaler Verlag der Wissenschaften.

Hindelang, Götz (1983). Einführung in die Sprechakttheorie. Tübingen: Max Niemeyer Verlag.

Kantorczyk, Ursula (2008). Pragmatik von Aufforderungshandlungen im Deutschen, Szczecin - Rostock: Print Group.

Komorowska, Ewa (2008). Pragmatyka dyrektywnych aktów mowy w języku polskim. Szczecin - Rostock: Print Group.

Komorowska, Ewa (2006). "Directive speech acts in linguistic communication". In: Piotr P. Chruszczewski, Michał Garcarz, Tomasz P. Górski (eds.). Język a komunikacja 10: At the Crossroads of Linguistic Sciences. Kraków: Tertium, 293-300.

Marcjanik, Małgorzata (2007). Grzeczność w komunikacji językowej. Warszawa: Wydawnictwo Naukowe PWN.

Misiukajtis, Joanna (2008). "Groźba jako akt mowy. Aspekt semantyczno-pragmatyczny". In: Ewa Komorowska, Anna Porchawka-Mulicka (eds.). Swiat Słowian w języku i kulturze IX: Językoznawstwo. Semantyka. Pragmatyka. Kognitywizm. Szczecin: Print Group Daniel Krzanowski, 107-110.

Nęcki, Zbigniew (2005). Komunikacja międzyludzka. Kluczbork: Oficyna Wydawnicza Drukarnia Antykwa.

Ożóg, Kazimierz (1982). "Podziękowania w polszczyźnie mówionej”. Język Polski LXII/4-5: 259-266.

Pisarkowa, Krystyna (1976). "Pragmatyczne spojrzenie na akt mowy". Polonica 2: 265-279.

Prokop, Izabela (2010). Aspekty analizy pragmalingwistycznej. Poznań: Wydawnictwo Naukowe UAM.

Pytel-Pandey, Danuta (2014). "Komunikacyjna charakterystyka aktów rady, ostrzeżenia i groźby”. In: Iwona Łuczków, Michał Sarnowski (eds.). Wyraz i zdanie w językach słowiañskich 8: Opis, konfrontacja, przekład. Wrocław: Wydawnictwo Uniwersytetu Wrocławskiego, 357-366. 
Wierzbicka, Anna (1973). "Akty mowy". In: Maria Renata Mayenowa (ed.). Semiotyka i struktura tekstu. Studia poświęcone VII Międzynarodowemu Kongresowi Slawistów. Wrocław: Ossolineum, 201221.

Joanna Misiukajtis ORCID iD: 0000-0002-2060-4624

Independent Scholar

joanna.misiukajtis@gmail.com 